\title{
Validation of InnoSPICE for Technology Transfer
}

\author{
Antanas Mitasiunas ${ }^{1}$, Jeremy Besson ${ }^{2}$, \\ Michael Boronowsky ${ }^{3}$, Tanja Woronowicz ${ }^{4}$, \\ ${ }^{1,2}$ Vilnius University, MitSoft UAB, Lithuania, ${ }^{3,4}$ University of Bremen, Germany
}

\begin{abstract}
Innovation and technology transfer consist mainly of process-oriented activities and can be described in processoriented terms by an innovation and technology transfer process capability model such as InnoSPICE. To verify such a thesis, an extended validation of the InnoSPICE adequacy for different factual innovation and technology transfer activities is needed. The purpose of this paper is to validate the InnoSPICE model for technology transfer led by a technology developer based on capability assessment of technology transfer process for several various research results.
\end{abstract}

Keywords - Innovation, process capability maturity, technology transfer.

\section{INTRODUCTION}

Some three decades ago, software developers started to seek for established and confirmed procedures and solutions to cope with the software crisis which was caused by recurrently exceeding project costs and schedules as well as the failure of functionality and quality. Inspired by traditional engineers, the software engineering community has developed standards and models such as ISO/IEC 15504 [1], [2], CMMI [3]-[5], and iCMM [6], [7]. These have been used by numerous software organizations around the world for guiding tremendous improvements in their ability to improve productivity and quality. The concept of software process capability, which expresses process predictability, became an efficient working tool for process and product quality management.

The results of software engineering in terms of software processes were generalized to any process capability assessment and improvement. Based on these experiences, other domains such as education and innovation management, followed. Comparable to software engineering, these two domains consist of mainly creative activities in the sense of being very knowledge intense and having little determinacy. After software engineering has been depicted into process-oriented terms, the validated innovation and knowledge transfer process capability maturity model [8]-[10] and the education process capability model [11] are further successful confirmations for the expression of creative activities in process-oriented terms.

\section{Motivation AND PROCESS CAPABILITY MATURITY}

How to keep software projects within a planned scope, schedule and resources? Out of all the innovative disclosures only $1 \%$ to $2 \%$ result in sustainably successful commercial enterprises [12]. How to achieve better results in knowledge and technology commercialization? How to improve education? How to improve learning? How to improve export? How to improve services of public sector institutions? How to improve enterprise performance? There are many more similar questions. Some of these tasks have already been resolved, some are under development and some need to be addressed in the future. These tasks are different. At the same time, the need for improvement of process-oriented activities is common for all these tasks, if learning is understood as a process-oriented activity, too.

Process capability modeling elaborated by the worldwide software engineering community during the last 25 years has become the tool for systematization and codifying knowledge and experiences of process-oriented activities. This is designed to improve predictability of activity results, i.e., to improve activity process capability. As a result of process capability modeling evolution, ISO/IEC 15504 defines a process capability dimension and the requirements for any external process definition to be applicable within the process dimension. Particular external model is Enterprise SPICE [13] that defines a domain independent integrated model for enterprise-wide assessments and improvement.

The software engineering community considerably contributed to the state of the art of process modeling: when numerous attempts to solve the software crisis applying technological and methodological approaches were not successful, software engineers consequently turned to organizational issues aiming to keep software projects within the planned scope, schedule and resources.

This approach is based on the assumption that product quality can be achieved by means of process quality - process capability. High process capability cannot be established at once during the launch of an activity. It only can be improved applying an iterative procedure of process capability assessment and improvement.

The research in this area is based on ideas, which originated from capability maturity models (CMMs) developed since 1987 by the Software Engineering Institute (SEI) of Carnegie Melon University. These models have evolved into CMMI version 1.3 [3]-[5] known as CMMI for Development, CMMI for Acquisition and CMMI for Services.

In parallel, the international community has developed an international standard for process assessment ISO/IEC 15504: Process assessment framework, also known as project SPICE (Software Process Improvement and Capability dEtermination) initiated by the UK Ministry of Defense in 1991.

ISO/IEC 15504 represents the third generation of process capability maturity models, which refer to an external process reference model. The process capability assessment framework is defined in the normative part of ISO/IEC 15504-2 [1].

In this context, an approach taken by ISO/IEC 15504 referring to the external process reference model is particularly important. It enables to extend the model application area outside software 
engineering. An external process reference model must satisfy the requirements of process definition in terms of process purpose and outcomes.

The third main source in the process capability maturity arena is iCMM v2.0 (integrated Capability Maturity Model), leading to the issues of model integration and architecture representation, developed by the US Federal Aviation Administration in 2001. It had significant impact on the current state of CMM area [6] and is along the same line as ISO/IEC 15504 (SPICE) and CMMI models. Based on an external process reference model approach, the convergence of SPICE and iCMM models is possible and, in fact, it is completed as the Enterprise SPICE initiative [13]. FAA iCMM is the baseline for development of SPICE conformant Enterprise Process Reference Model (PRM) and a supplementing Process Assessment Model (PAM). Enterprise SPICE has been developed by a joint effort of more than one hundred experts representing 31 countries from all continents. The first stage of Enterprise SPICE [13] project is completed and it is in process of ISO/IEC 330xx standardization.

Hundreds of various generic and specific organizational maturity models have been developed. Among them [14] is of particular importance in this context. Usually maturity models provide the characteristics of maturity levels. However, very few of them provide a decomposition of an activity modeled as a collection of processes defined in minimal terms, namely, in terms of process name, process purpose and process outcomes.

\section{TECHNOLOGY TRANSFER PROCESS CAPABILITY MODELING}

Innovation, knowledge and technology transfer improvement is a complex domain with many intangible benefits and obstacles. Conventionally, the management of innovation, knowledge and technology transfer activities is a "black box" based approach, comparing inputs and outputs or using statistical data. The approach taken here is a "white box" approach, i.e., the innovation, knowledge and technology transfer activities are decomposed into a set of processes and their performance descriptions. An important concern about such an approach is how it reflects on the creative aspects of any innovation and transfer activity. Of course, creativity cannot be modeled by process-based notions, but the question arises: "Is the transfer of knowledge and technologies towards innovation a completely creative activity?" If yes, then a process-oriented approach would not be suitable for innovation, knowledge and technology transfer process modeling.

The approach to codify process-oriented knowledge for creative activity modeling is based on the successful experience of software engineering community in software development process modeling. At first sight, software development can be seen as a completely creative activity. However, it was modeled by tens of processes, hundreds of practices and work products. Of course, there remain creative elements, but they do not eliminate the process-oriented approach as a whole.

Process capability characteristics are related to process result predictability. Organizational maturity expresses the way how organization's activities are performed - the improvement path of defined activities for achieving predefined results. The process capability concept enables measuring the state of performance of an organization's activities and to plan precise steps for process capability improvement.

An innovation concept is close to the understanding of improvement, because any innovation contains inherent improvement. Per definition, an innovation is a new product, process, service or work environment implemented with value [15]. Thus, an innovative organization is an improving organization. And, thus, knowledge transformation towards value added and/or knowledge commercialization is an innovation process.

The full value chain of innovation can be modeled based on three pure roles: knowledge development, transfer of knowledge and its implementation. In the real world set up, organizations can perform one, two or all three of these pure roles. Fundamental research institutions, for example, perform mainly knowledge development while applied research institutions often develop knowledge and transfer it into practice. Industrial corporations can develop knowledge, transfer and implement it. The knowledge and best practice experiences related to these three roles compose the body of modeling innovation, knowledge and technology transfer.

The process capability modeling approach can be applied to improve innovativeness of an organization. Modeling of organization's domain independent activities can reuse the Enterprise SPICE Organizational, Life cycle and Support process categories. The innovation related activities can be modeled by the Application process category.

Enterprise SPICE processes are ISO/IEC 15504 conformant. To be able to apply the ISO/IEC 15504 capability framework, the processes of the Application category also must satisfy the requirements of ISO/IEC 15504 for process descriptions. From there, an application dependent ISO/IEC 15504 conformant process capability model can be built by development of an Application process category, reuse of Enterprise SPICE Organizational, Life cycle and Support process categories and reuse of the ISO/IEC 15504 capability framework.

An application domain independent process capability model by definition cannot contain domain specific features. However, process capability improvement is domain specific. Such a gap can be addressed by external consultants or by the process owner, if the process capability model contains domain specific knowledge and enable tracing the model's wording to the organization's activity which should be improved. An application domain dependent process capability model enables a participative approach towards process capability improvement as introduced here. On the other hand, a participative approach to process capability improvement reinforces the importance of application domain dependent process capability modeling.

A process reference model is more abstract than a process assessment model. However, a process assessment model always remains more abstract than a real organization's activity model. A unified assessment model must be suitable to assess and represent in unified terms the assessment results of various different organizations. On the other hand, the granularity of an 
assessment model should be sufficiently high to achieve comparable assessment results and to avoid too big assessment mistakes.

Thus, three levels of abstraction of the process dimension can be distinguished:

- Process Reference Model - identification of processes defined in minimal terms, namely, a process name, a process purpose and the process outcomes;

- Process Assessment Model (PAM) - in addition to the process description within the Process Reference Model, it contains the description of several Base Practices and possibly work products. Successful performance of base practices ensures the achievement of the process purpose and the process outcomes. The PAM can be understood as a collection of best practices related to an organization's activity that is used as a reference standard for structuring, assessment, comparison and improvement of the organization's activity;

- Activity Model - a more detailed description of the real activity performed by a particular organization using a wording which is accepted by an organization.

Hence, a capability maturity model can be understood as codified process-oriented knowledge. Process capability maturity modeling can be treated as a method, system of notions, "language", tool, best practice etc. It allows equally for the knowledge systematization of process-oriented activities and the description of real activities performed by a particular institution. Application dependent process capability modeling can be applied:

- for the assessment of application area process capability performed by an institution;

- for the exchange of best practices contained within the application area activity model;

- for the definition of target process capability profiles based on assessment results and performance goals; and

- for the improvement of the application area activities to reach a target process capability profile using the available best practices.

The traditional approach to process capability assessment and improvement foresees a formal assessment performed by an external assessor or an assessment team and the preparation of an assessment report, including recommendations for process capability improvement. Such an approach suits well for process capability determination dedicated to external use. However, it is not sufficient for internal process improvement - people tend to agree more easy to perform processes internally defined by an institution rather than those defined by third parties.

\section{TeChNOlOgY TRANSFER PROCESS ScENARIOS}

There are four potential knowledge commercialization scenarios: a developer, an acquirer, a broker and a driver. Knowledge is understood here in wide sense and can be represented by any knowledge intensive artefact: a technology, a process, a product, a service, an infrastructure, a work environment, etc. A knowledge commercialization concept is close to an innovation concept. An innovation is the partial case of knowledge commercialization. The concept of innovation requires 'being new for an organization'. Knowledge commercialization means the transformation of a knowledge intensive artefact into added value for an organization.

The knowledge commercialization developer's scenario takes place when a knowledge creator or owner performs actions transforming his knowledge into economic value. The characteristics of such a scenario are that the supply scope is limited by knowledge possessed by a transfer initiator - a knowledge owner only. The main difficulty in this scenario is to describe knowledge value for a knowledge acquirer in his own terms. To some extent, the value definition of knowledge remains up to the acquirer. The knowledge commercialization developer's scenario can be classified as high knowledge on the supply side and little knowledge on the demand side. The main risk is taken by the knowledge developer if the knowledge is not to be commercialized. The impact of the risk depends on the financial sources for knowledge creation.

The knowledge commercialization acquirer's scenario takes place when a knowledge acquirer seeks for knowledge to create or increase value within his organization. The needed knowledge can be ready for use or to be developed according to the order of the acquirer. The acquirer knows the value of the knowledge in advance. In this scenario, a knowledge transfer process is driven by the acquirer and assisted by the knowledge creator, also known as customer driven development. The knowledge commercialization acquirer's scenario can be classified as a high amount of knowledge on the demand side and little knowledge on the supply side. The main risk is taken by the knowledge acquirer if the acquired knowledge does not generate the expected value for his organization. The impact of the risk is high.

The knowledge commercialization broker's scenario takes place when an active knowledge transfer intermediary takes the role to seek for knowledge acquirers' needs as well as for knowledge to be transferred while creating a demand-supply data base and/or a network of brokers. The primary action in this activity is catching the demand. The knowledge supply is secondary. It can be based on existing knowledge which is ready for use or can be developed according to the order of an acquirer. There are data provided by brokers that the success ratio is about one of 60 cases. The function of the broker in knowledge commercialization finishes when an agreement for knowledge transfer is concluded between a knowledge acquirer and a supplier. The knowledge commercialization broker's scenario can be classified as a low amount of knowledge on the demand side and a low amount of knowledge on the supply side. The main risk is taken by the knowledge broker if the knowledge transfer intermediation efforts are not successful. The impact of the risk is low because of generally limited investments into brokerage activities.

The knowledge commercialization driver's scenario takes place when the full responsibility for the knowledge transfer is up to a knowledge transfer driver. The knowledge transfer driver creates a knowledge commercialization loop with involvement of many players, including knowledge marketing managers, acquirers, developers, sponsors etc. The knowledge transfer driver's activity is based on a knowledge commercialization 
concept elaborated with the involvement of experts from the acquirer's side, development, marketing, financing communities and based on the complementarity of integrated efforts of various capabilities for value creation. The knowledge commercialization driver's scenario can be classified as a sufficient amount of knowledge on the demand side and a sufficient amount of knowledge on the supply side. The main risk is up to the knowledge transfer driver. The impact of the risk is high because of the concentration of responsibility into the driver's activity.

InnoSPICE transfer process category is provided in Table I.

TABLE I

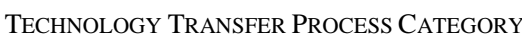

\begin{tabular}{|c|c|}
\hline Process name & Process purpose \\
\hline $\begin{array}{l}\text { 1. Technology } \\
\text { Transfer } \\
\text { Concept }\end{array}$ & $\begin{array}{l}\text { The purpose of the Technology Transfer Concept } \\
\text { process is to identify and develop a technology } \\
\text { transfer concept }\end{array}$ \\
\hline $\begin{array}{l}\text { 2. Initial Market } \\
\text { Assessment }\end{array}$ & $\begin{array}{l}\text { The purpose of the Initial Market Assessment process } \\
\text { is to assess clear contraindications that will severely } \\
\text { impede any move to a market if such exists }\end{array}$ \\
\hline $\begin{array}{l}\text { 3. Technology } \\
\text { Evaluation }\end{array}$ & $\begin{array}{l}\text { The purpose of the Technology Evaluation process is } \\
\text { to evaluate reasonability and technical viability of the } \\
\text { available technologies that might be transferred }\end{array}$ \\
\hline $\begin{array}{l}\text { 4. Technical } \\
\text { Analysis }\end{array}$ & $\begin{array}{l}\text { The purpose of the Technical Analysis process is to } \\
\text { refine all technical aspects of the potential technology } \\
\text { and to identify any areas that require further } \\
\text { development to meet cost or quality targets and/or } \\
\text { end user requirements }\end{array}$ \\
\hline $\begin{array}{l}\text { 5. Intellectual } \\
\text { Property } \\
\text { Protection } \\
\text { Determination }\end{array}$ & $\begin{array}{l}\text { The purpose of the Intellectual Property Protection } \\
\text { Determination process is to determine and follow on } \\
\text { the appropriate form of the protection for the } \\
\text { intellectual property }\end{array}$ \\
\hline $\begin{array}{l}\text { 6. Market and } \\
\text { Competitive } \\
\text { Analysis }\end{array}$ & $\begin{array}{l}\text { The purpose of the Market and Competitive Analysis } \\
\text { process is to evaluate the market potential of the } \\
\text { technology to be transferred }\end{array}$ \\
\hline $\begin{array}{l}\text { 7. Technology } \\
\text { Value } \\
\text { Evaluation }\end{array}$ & $\begin{array}{l}\text { The purpose of the Technology Value Evaluation } \\
\text { process is to evaluate the innovative technology on } \\
\text { the basis of its relative value and the commitment of } \\
\text { the potential acquirers }\end{array}$ \\
\hline $\begin{array}{l}\text { 8. Go-to-Market } \\
\text { Estimation }\end{array}$ & $\begin{array}{l}\text { The purpose of the Go-to-Market Estimation process } \\
\text { is to determine how quickly the technology can be } \\
\text { brought to the marketable stage and to plan } \\
\text { technology subsequent improvements and } \\
\text { innovations to establish on-going demand and } \\
\text { aftermarket potential }\end{array}$ \\
\hline $\begin{array}{l}\text { 9.Commercial/ } \\
\text { Social- } \\
\text { economic } \\
\text { Interest } \\
\text { Confirmation } \\
\end{array}$ & $\begin{array}{l}\text { The purpose of the Commercial/Social-economic } \\
\text { Interest Confirmation process is to define commercial } \\
\text { or social-economic interest and to identify the most } \\
\text { promising route into the target market }\end{array}$ \\
\hline $\begin{array}{l}\text { 10. Business } \\
\text { Case } \\
\text { Establishment }\end{array}$ & $\begin{array}{l}\text { The purpose of the Business Case Establishment } \\
\text { process is to build up the strongest possible business } \\
\text { case for the innovative technology }\end{array}$ \\
\hline $\begin{array}{l}\text { 11. Go-to- } \\
\text { Market Strategy } \\
\text { Establishment }\end{array}$ & $\begin{array}{l}\text { The purpose of the Go-to-Market Strategy } \\
\text { Establishment process is to select flexibly and } \\
\text { objectively a go-to-market approach with the highest } \\
\text { perceived commercial/social-economic potential }\end{array}$ \\
\hline $\begin{array}{l}\text { 12. Business } \\
\text { Plan } \\
\text { Establishment }\end{array}$ & $\begin{array}{l}\text { The purpose of Business Plan Establishment process } \\
\text { is to develop and maintain the document that will } \\
\text { allow investors and other technology transfer } \\
\text { participants to evaluate the background, current status } \\
\text { and real market/social-economic potential of the } \\
\text { venture }\end{array}$ \\
\hline $\begin{array}{l}\text { 13. Financing } \\
\text { Source Raising }\end{array}$ & $\begin{array}{l}\text { The purpose of the Financing Source Raising process } \\
\text { is to identify appropriate sources of financing and to } \\
\text { select the investors with a clear understanding of } \\
\text { what they see as their future role as investors over the } \\
\text { coming years }\end{array}$ \\
\hline
\end{tabular}

\section{TECHNOLOGY TRANSFER PROCESS DEVELOPER'S SCENARIO}

The task to create an appropriate research result transfer concept according to knowledge commercialization developer's scenario is one of the main challenges in technology transfer. An approach to elaborate such a scenario is based on the questionnaire built according to the innoSPICE methodology. This questionnaire foresees the interaction of a knowledge developer and an acquirer. However, in this scenario a knowledge developer is the initiator of the knowledge transfer process. A knowledge developer should fill in the questionnaire as much as possible comprehensively to describe the transferable knowledge for potential target groups. A knowledge acquirer then might provide complementary clarifications representing the demand side. One or several iterations of this exchange should be foreseen.

The structure of the questionnaire for the knowledge commercialization developer's scenario is provided below in Table II.

TABLE II

TeChNOLOGY TRANSFER PROCESS QUESTIONNAIRE

\begin{tabular}{|c|c|}
\hline 1. & Research Results $(<\mathbf{R R}\rangle)$ transfer concept \\
\hline 1.1. & Identify $\langle\mathbf{R R}\rangle$ that could be transferred to the target group \\
\hline 1.2. & Identify the target group for which $\langle\mathbf{R R}\rangle$ would be useful \\
\hline 1.3. & Obtain the target group needs \\
\hline 1.4. & Describe $<\mathbf{R R}>$ use scenarios by the target group \\
\hline 1.5 . & $\begin{array}{l}\text { Describe }<\mathbf{R R}>\text { use benefit for the target group in terms of the } \\
\text { target group }\end{array}$ \\
\hline 1.6. & Evaluate $<\mathbf{R R}>$ transfer opportunities for the target group \\
\hline 1.7. & Establish $<\mathbf{R R}>$ transfer concept for the target group \\
\hline 2. & $<\mathbf{R R}>$ initial (fast) market assessment of the target group \\
\hline 2.1. & $\begin{array}{l}\text { Establish "negative" criteria for discontinuing }\langle\mathbf{R R}>\text { transfer to } \\
\text { the target group } \\
\text { Remark: "negative" means an indicator that stops or seriously } \\
\text { hampers transfer. Such criteria are used for fast negative } \\
\text { market assessment. }\end{array}$ \\
\hline 2.2 . & $\begin{array}{l}\text { Identify contraindications to move with }<\mathbf{R R}>\text { transfer to the } \\
\text { target group }\end{array}$ \\
\hline 2.3 . & $\begin{array}{l}\text { Assess "negatively" }<\mathbf{R R}>\text { components to be transferred to the } \\
\text { target group from the point of view of "negative" criteria and } \\
\text { contraindications }\end{array}$ \\
\hline 2.4. & $\begin{array}{l}\text { Document and report "negative" assessment results for decision } \\
\text { makers }\end{array}$ \\
\hline 3. & $\langle\mathbf{R R}>$ evaluation for transfer suitability to the target group \\
\hline 3.1. & $\begin{array}{l}\text { Define available }<\mathbf{R R}>\text { components related to the target group } \\
\text { needs }\end{array}$ \\
\hline 3.2 . & $\begin{array}{l}\text { Assess available }<\mathbf{R R}>\text { component transfer suitability for the } \\
\text { target group needs }\end{array}$ \\
\hline 3.3 . & $\begin{array}{l}\text { Ensure documentation of }\langle\mathbf{R R}>\text { components to be transferred to } \\
\text { the target group }\end{array}$ \\
\hline 3.4 . & $\begin{array}{l}\text { Create list of }<\mathbf{R R}>\text { components to be transferred to the target } \\
\text { group }\end{array}$ \\
\hline 3.5 . & $\begin{array}{l}\text { Establish }<\mathbf{R R}>\text { component support and maintenance } \\
\text { procedures }\end{array}$ \\
\hline 4. & $\begin{array}{l}\text { Technical analysis of }\langle\mathbf{R R}\rangle \text { components to be transferred to the } \\
\text { target group }\end{array}$ \\
\hline 4.1. & Derive the target group requirements \\
\hline 4.2 . & Record and change control target group requirements \\
\hline 4.3 . & $\begin{array}{l}\text { Trace consistency of }<\mathbf{R R}>\text { components with the target group } \\
\text { requirements }\end{array}$ \\
\hline 4.4. & Refine $<\mathbf{R R}>$ components to be transferred to the target group \\
\hline 4.5. & $\begin{array}{l}\text { Identify further development of }<\mathbf{R R}>\text { components to meet } \\
\text { quality and cost objectives }\end{array}$ \\
\hline
\end{tabular}




\begin{tabular}{|c|c|}
\hline 5. & $\begin{array}{l}\text { Determination of intellectual property protection of }\langle\mathbf{R R}\rangle \\
\text { components to be transferred to the target group }\end{array}$ \\
\hline 5.1. & Establish IP protection strategy \\
\hline 5.2 . & Verify feasibility to establish a new IP \\
\hline 5.3. & Select IP protection form \\
\hline 5.4. & Develop IP protection policy \\
\hline 5.5. & Register Intellectual Property \\
\hline 5.6. & Monitor IP inviolability \\
\hline 6. & $\begin{array}{l}\text { Market and competitive analysis of }\langle\mathbf{R R}>\text { components to be } \\
\text { transferred to the target group }\end{array}$ \\
\hline 6.1. & $\begin{array}{l}\text { Define positioning in the market of }\langle\mathbf{R R}>\text { components to be } \\
\text { transferred to the target group }\end{array}$ \\
\hline 6.2. & Obtain the target group reaction \\
\hline 6.3. & Perform Beta testing \\
\hline 6.4 . & Perform the market and competitive analysis \\
\hline 7. & $\begin{array}{l}\text { Value evaluation of }\langle\mathbf{R R}\rangle \text { components to be transferred to the } \\
\text { target group }\end{array}$ \\
\hline 7.1. & $\begin{array}{l}\text { Analyze advantages of }\langle\mathbf{R R}\rangle \text { components to be transferred to } \\
\text { the target group in financial, performance and experience terms }\end{array}$ \\
\hline 7.2 . & $\begin{array}{l}\text { Establish value of }\langle\mathbf{R R}>\text { components to be transferred to the } \\
\text { target group such as cost savings, increased earning power, } \\
\text { increased performance and decreased undesirable effects }\end{array}$ \\
\hline 7.3 . & $\begin{array}{l}\text { Contribute to the target group value delivery system by } \\
\text { considering potential synergy exploitation }\end{array}$ \\
\hline 7.4 . & $\begin{array}{l}\text { Identify the target group potential benefit on obtaining of }\langle\mathbf{R R}\rangle \\
\text { components using }\langle\mathbf{R R}\rangle \text { communication and distribution } \\
\text { channels }\end{array}$ \\
\hline 7.5 . & $\begin{array}{l}\text { Develop }<\mathbf{R R}>\text { components value proposition statements to the } \\
\text { target group }\end{array}$ \\
\hline 8. & $\begin{array}{l}\text { Go-to-market estimation of }\langle\mathbf{R R}\rangle \text { components to be transferred } \\
\text { to the target group }\end{array}$ \\
\hline 8.1. & $\begin{array}{l}\text { Define a life cycle strategy of }\langle\mathbf{R R}>\text { components to be } \\
\text { transferred to the target group }\end{array}$ \\
\hline 8.2 . & $\begin{array}{l}\text { Define "marketable stage" criteria for }\langle\mathbf{R R}\rangle \text { components to be } \\
\text { transferred to the target group }\end{array}$ \\
\hline 8.3 . & $\begin{array}{l}\text { Determine how quickly }<\mathbf{R R}>\text { components can be brought to } \\
\text { the "marketable stage" }\end{array}$ \\
\hline 8.4. & Evaluate the risk of delay \\
\hline 8.5 . & $\begin{array}{l}\text { Plan subsequent improvements of }\langle\mathbf{R R}\rangle \text { components to the } \\
\text { target group }\end{array}$ \\
\hline 9. & $\begin{array}{l}\text { Confirmation of transfer interest of }\langle\mathbf{R R}\rangle \text { components to be } \\
\text { transferred to the target group }\end{array}$ \\
\hline 9.1. & $\begin{array}{l}\text { Assess total cost and revenue of }\langle\mathbf{R R}\rangle \text { components to be } \\
\text { transferred to the target group }\end{array}$ \\
\hline 9.2. & $\begin{array}{l}\text { Define the target market qualitatively and quantitatively of } \\
\langle\mathbf{R R}>\text { components to be transferred }\end{array}$ \\
\hline 9.3. & $\begin{array}{l}\text { Compare minimum revenue to cover the cost of }\langle\mathbf{R R}\rangle \\
\text { components to be transferred to the target group }\end{array}$ \\
\hline 9.4 . & $\begin{array}{l}\text { Identify the most promising preliminary route into the target } \\
\text { market }\end{array}$ \\
\hline 10. & $\begin{array}{l}\text { Business case establishment for }\langle\mathbf{R R}>\text { components to be } \\
\text { transferred to the target group }\end{array}$ \\
\hline 10.1. & $\begin{array}{l}\text { Establish a business case strategy of }\langle\mathbf{R R}\rangle \text { components to be } \\
\text { transferred to the target group, including issues such as } \\
\text { licensing, sale, new start-up establishment }\end{array}$ \\
\hline 10.2 . & $\begin{array}{l}\text { Define business case alternatives, evaluation criteria, evaluation } \\
\text { and selection of alternatives }\end{array}$ \\
\hline 10.3 . & Build a business case \\
\hline 11. & $\begin{array}{l}\text { Go-to-market strategy establishment for }\langle\mathbf{R R}\rangle \text { components to } \\
\text { be transferred to the target group }\end{array}$ \\
\hline 11.1. & $\begin{array}{l}\text { Define go-to-market strategy alternatives for }\langle\mathbf{R R}\rangle \text { components } \\
\text { to be transferred to the target group, including issues such as } \\
\text { licensing or sale to the existing company, new start-up } \\
\text { establishment, establishment of joint venture with the existing } \\
\text { transfer participant in the target market }\end{array}$ \\
\hline
\end{tabular}

\begin{tabular}{|l|l|}
\hline 11.2. & $\begin{array}{l}\text { Define evaluation criteria of go-to-market strategy alternatives, } \\
\text { evaluation and selection of alternatives }\end{array}$ \\
\hline 11.3. & Establish a go-to-market strategy \\
\hline 12. & $\begin{array}{l}\text { Business plan establishment for }<\mathbf{R R}>\text { components to be } \\
\text { transfer to the target group }\end{array}$ \\
\hline 12.1. & $\begin{array}{l}\text { Provide background material on }<\mathbf{R R}>\text { components to be } \\
\text { transferred to the target group }\end{array}$ \\
\hline 12.2. & $\begin{array}{l}\text { Define current status of }<\mathbf{R R}>\text { component transfer to the target } \\
\text { group }\end{array}$ \\
\hline 12.3. & $\begin{array}{l}\text { Establish market potential of }<\mathbf{R R}>\text { components to be } \\
\text { transferred to the target group }\end{array}$ \\
\hline 12.4. & $\begin{array}{l}\text { Establish a business plan to allow investors and other } \\
\text { stakeholders to evaluate a situation and to take decision on the } \\
\text { venture participation }\end{array}$ \\
\hline 13. & $\begin{array}{l}\text { Financing source raising for }<\mathbf{R R}>\text { components to be } \\
\text { transferred to the target group }\end{array}$ \\
\hline 13.1. & $\begin{array}{l}\text { Identify sources of financing for }<\mathbf{R R}>\text { components to be } \\
\text { transferred to the target group }\end{array}$ \\
\hline 13.2. & Analyze venture's operation successful scenarios \\
\hline 13.3. & Define financial flows \\
\hline 13.4. & Establish requirements for on-going financing \\
\hline 13.5. & $\begin{array}{l}\text { Communicate the financial flows and requirements for on-going } \\
\text { financing }\end{array}$ \\
\hline 13.6. & Select prospective investors \\
\hline
\end{tabular}

\section{PILOT R\&D FOR TRANSFER PROCESS VALIDATION}

The validation of the technology transfer process model InnoSPICE is based on a transfer experiment by the technology developer's scenario of four different research results:

- InnoSPICE ${ }^{\circledR}$ - Innovation, Technology and Knowledge Transfer Process Capability Model;

- eLOGMAR-M - Web-based and Mobile Solutions for Collaborative Work Environment with Logistics and Maritime Applications;

- Virtual Reality Framework, Engineering and Applications;

- Signa ${ }^{\circledR}$ - A Product line Signa ${ }^{\circledR}$ for electronic document creation and verification.

\section{A. InnoSPICE $®$ - Innovation, Technology and Knowledge Transfer Process Capability Model}

The main results of the INTERREG IVb Baltic Sea Region project BONITA [10] are the development of an Enhanced Innovation and Technology Transfer Model and a network of showrooms in the consortium partners' institutions.

The goal of the Enhanced Innovation and Technology Transfer Model [8] is to provide the basis for implementing different regional innovation and technology transfer models within the Baltic countries and regions, and to facilitate the creation and operational running of the transnational BONITA network.

The Enhanced Innovation and Technology Transfer Model is based on the Process Capability Maturity Models elaborated by the software engineering community and on best practices of real innovation and technology transfer activities.

The technology transfer process typically includes a set of components, starting with investment in R\&D, the actual R\&D performance, decision how to handle intellectual property, building a prototype to demonstrate the technology, the further development needed for commercialization and finally resulting 
in the successful introduction of a product or service to the market.

The success of technology transfer depends on the interaction between all actors: technology developers, technology transfer drivers and technology acquirers and their ability to tackle a number of challenges along the way, e.g., they should prove that the technology or concept works, decide when to patent, negotiate licensing terms, secure necessary capital investment in several stages, put together a skilled management team, identify the value or utility to the user/customer, create a business plan and a strategy for going to market.

The description presents a continuous architecture of the model. The process dimension of the continuous architecture provides a process reference and process assessment models. It shows how an approach taken is inspired by and contributes to these frameworks. The structure of the Enhanced Innovation and Technology Transfer Model and the description of its associated processes are grouped according to their process categories. The model contains a full description of a process reference model and a process assessment model. The staged representation of the Enhanced Innovation and Technology Transfer Capability Maturity Model and the attribution of the processes for a particular maturity level are provided, as well.

\section{B. eLOGMAR-M - Web-based and Mobile Solutions for Collaborative Work Environment with Logistics and Maritime Applications}

The functioning of the market economy depends largely on the effective information provision about transport services. It is highly important to reach synchronization of business processes, cargo and data flows and the integrity among different activities accompanying cargo transportation along a selected freight route. In order to address these issues, the eLOGMAR-M project was funded by the European Commission within the Sixth Framework Programme (DG INFSO) [16].

The main goal of the eLOGMAR-M project was to create a web portal for information provision to transport service consumers. The major idea from logistics' point of view is to estimate a start-to-finish rate of cargo transportation and to select the most suitable supply chain.

Actors from two major target groups are involved in a cargo transportation process:

- Transportation group: deep sea and feeder shipping lines, ship owners, terminal operators, block train operators, forwarding companies, multimodal transportation operators, freight brokers;

- Cargo group: cargo owners, traders.

The main approach has been customized into the web portal www.elogmar.eu. The portal enables users:

- to calculate transportation cost of cargo (bought goods) from purchasing place to the destination in accordance with Incoterms 2000;

- to estimate expected transit time of cargo delivery to the destination;

- to choose the transport company, which corresponds to their requirements and is engaged in transportation of containers;
- to assess the service level of selected company engaged in cargo transportation.

\section{Virtual Reality Framework, Engineering and Applications}

Virtual and augmented reality technologies have made enormous advances in recent years: Germany holds a leading position internationally.

The project acronym ViVERA stands for Virtual Competence Network for Virtual and Augmented Reality [17]. The network combined ten institutes and universities' research resources in the field of virtual and augmented reality nationwide.

ViVERA has set itself the task of networking developers and users' expertise and experience and sustainably integrating virtual technologies in business and industry. Among other things, demonstrators were prototyped, which demonstrates the potential and diverse potential applications of VR and AR technologies in the widest variety of fields.

Research results are documented in a knowledge base and integrated in the international research scene. They are thus made accessible to a wide circle of potential users. The Virtual Development and Training Centre of the Fraunhofer IFF serves as a contact for technology transfer and it establishes contact with the cooperating research partners.

The excellence network of ViVERA is equipped with extensive experiences from already completed projects. The associates are developing customized applications together with their clients from the business communities. The researchers provide consulting when virtual technologies are implemented in companies and develop individual software solutions completely made-to-order.

\section{Signa ${ }^{\circledR}-$ A Product Line Signa ${ }^{\circledR}$ for Electronic Document Creation and Verification}

Product line Signa ${ }^{\circledR}[18]$ enables one to create and verify electronic documents that are signed with qualified electronic signatures according to the specification ADOC for unstructured human readable electronic documents and according to the specification MDOC for structured computer readable electronic documents:

- Signa ${ }^{\circledR}$ Desktop - Windows OS application available for download from www.mitsoft.lt;

- Signa ${ }^{\circledR}$ Web - web application available at https://signa.mitsoft.lt;

- Signa ${ }^{\circledR}$ Docs - web application for enterprises featuring multiple users, electronic document workflows and the ability to sign with qualified signatures multiple electronic documents in bulk;

- Signa ${ }^{\circledR}$ SDK - a set of application libraries for Java and .NET platforms that implement XAdES standards and allow integrating the Signa ${ }^{\circledR}$ functionality into external software systems.

The product line Signa ${ }^{\circledR}$ supports the whole lifecycle of electronic documents, starting from the document creation and signing up to archiving. It supports most known secure signature creation device types: integrated circuit cards, USB tokens, mobile operator SIM cards. 
MitSoft's solution for signed electronic documents is flexible and universal - it can be easily used by individuals, small businesses, corporate customers and public sector organizations. For example, a citizen of Lithuania would need only his national identity card containing his qualified certificate in order to sign an electronic document. With the identity card and a USB reader, he would be able to use web application to create, sign or verify an electronic document. Such a document would contain then his individual signature and would serve as a trusted input for the recipient, as the recipient would be able to verify the authenticity of the received document. Alternatively, both parties can download and install the Signa ${ }^{\circledR}$ Desktop application.

\section{INNOSPICE VALIDATION RESULTS}

Validation methodology. Based on generic technology transfer process questionnaire provided in Table II, tailored questionnaires for the transfer of all four piloting research results were developed and filled in by the developers of each result potentially to be transferred.

The technology transfer process capability was assessed for all 13 processes of technology transfer process category based on information coming from completed questionnaires and provided during interviews with developers of these technologies.

Process performance is assessed by evaluating performance of process base practices. Each base practice has a corresponding question in the questionnaire. The answers to the questions about performance of a corresponding base practice were rated on the basis of a four grade scale: $\mathrm{N}$ - Not performed, $\mathrm{P}$ - Partially performed, L - Largely performed and F - Fully performed using a percentage from 0 to 100 . Full interval [0, $100]$ of possible values of practice performance assessment is split into four subintervals: [0, 15], [16, 50], [51, 85], [86, 100] for grades $\mathrm{N}, \mathrm{P}, \mathrm{L}$ and $\mathrm{F}$, respectively. The assessment of base practice performance is limited by assessment scope in terms of organizational units and their projects.

The transfer process capability assessment results are provided as process capability profiles for all 4 piloted research results.

\section{A. InnoSPICE ${ }^{\circledR}$ Transfer Process Capability}

The InnoSPICE $®$ transfer process capability profile provided in Fig. 1 indicates strengths and weaknesses that characterize the actual situation in a transfer process performed by the knowledge or technology developer:

Strengths. The technology developer knows and performs a transfer process at a conceptual level. Intellectual property of the innovation, knowledge and technology transfer process model InnoSPICE ${ }^{\circledR}$ is protected by a trademark registered in the EU. From the developer's point of view, the readiness of InnoSPICE ${ }^{\circledR}$ commercialization for a target market is high.

Weaknesses. The weaknesses are mainly related to the inaccurate knowledge about specific needs of the target market and accordingly to actions depending on such needs.

Fig. 1. InnoSPICE $®$ transfer process capability profile.

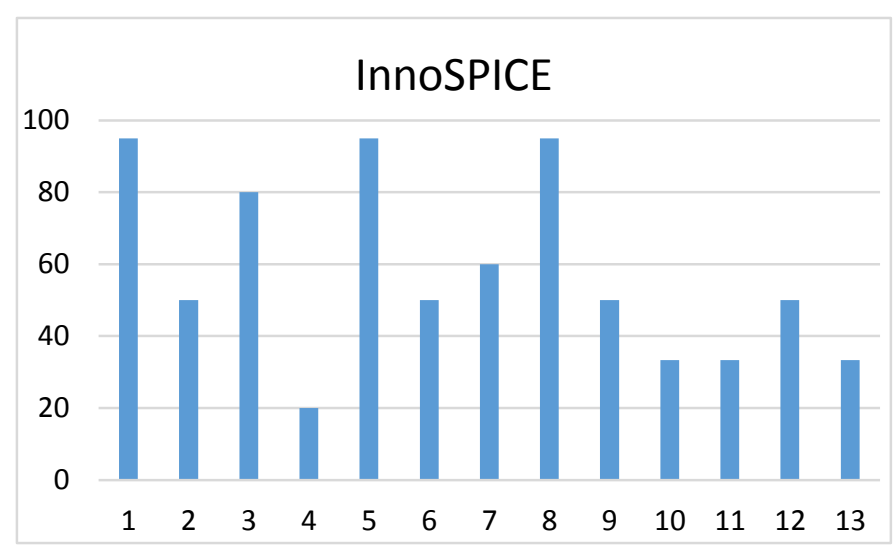

B. eLOGMAR Transfer Process Capability

The eLOGMAR transfer process capability profile provided in Fig. 2 characterizes the case of a transfer process when the transferable technology is already adapted to the needs of a defined target group but not transferred yet.

Strengths. In addition to the high performance of the transfer process at a conceptual level, the technology evaluation process for reasonability and technical viability of the available technologies is also well performed. The readiness of the eLOGMAR transfer to a defined target market is high, as well.

Weaknesses. At the moment, a business case establishment process is not performed at all.

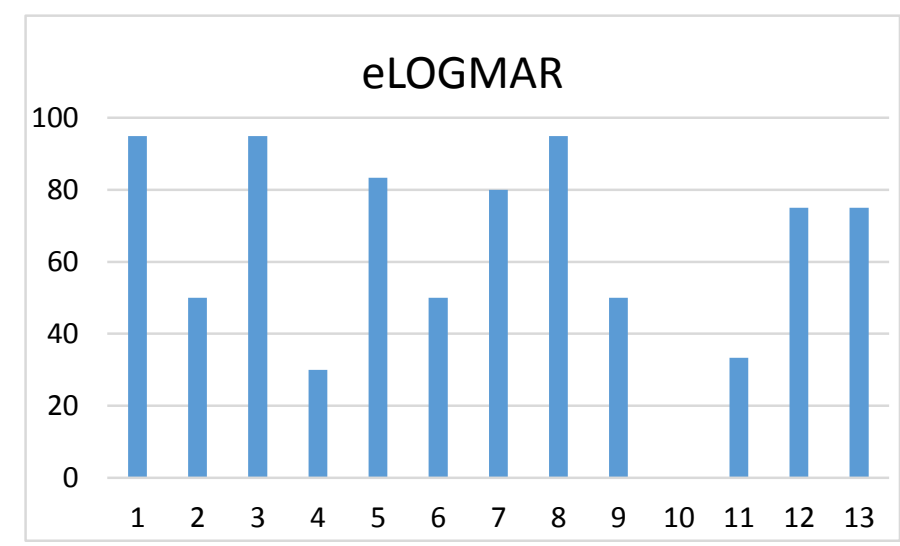

Fig. 2. eLOGMAR transfer process capability profile.

\section{Virtual Reality Transfer Process Capability}

The Virtual Reality transfer process capability profile is provided in Fig. 3. The particularity of this technology transfer process case is that Virtual Reality technology is already transferred from IFF, Germany, to Astana Innovations, Kazakhstan. This strength is clearly indicated by the high capability of the business case establishment process.

Virtual Reality technology was transferred as it is and this is reflected in the capability of the technical analysis process for identifying areas of further development to meet the end user requirements. 


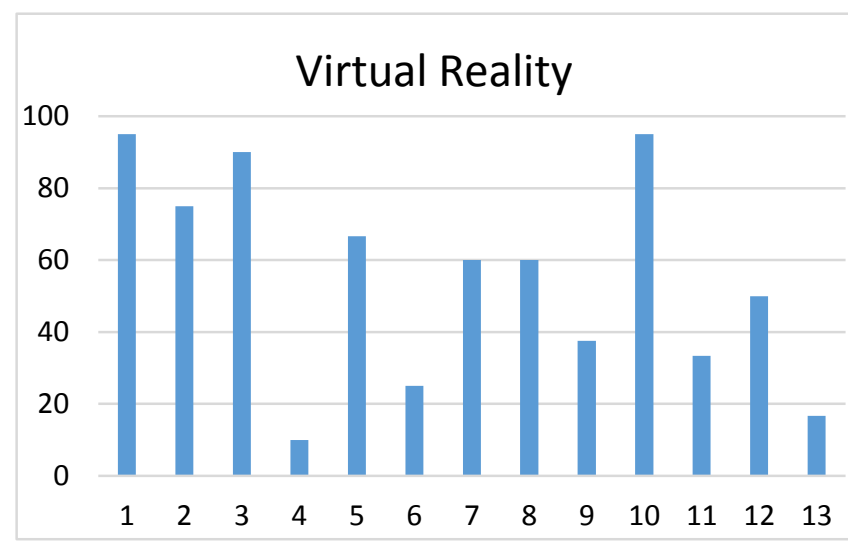

Fig. 3. Virtual Reality transfer process capability profile.

\section{Signa ${ }^{\circledR}$ Transfer Process Capability}

The Signa ${ }^{\circledR}$ transfer process capability profile provided in Fig. 4 indicates the strengths and weaknesses of the transfer process of a highly innovative solution for electronic documents having the same legal power as hand signed documents. Using this solution, the Lithuanian government in 2011 became the first government in the word issuing legal acts only as electronic documents signed by qualified electronic signatures. Correspondingly, the Lithuanian Seimas (parliament) is the first in the world that started issuing all legal acts as electronic originals only.

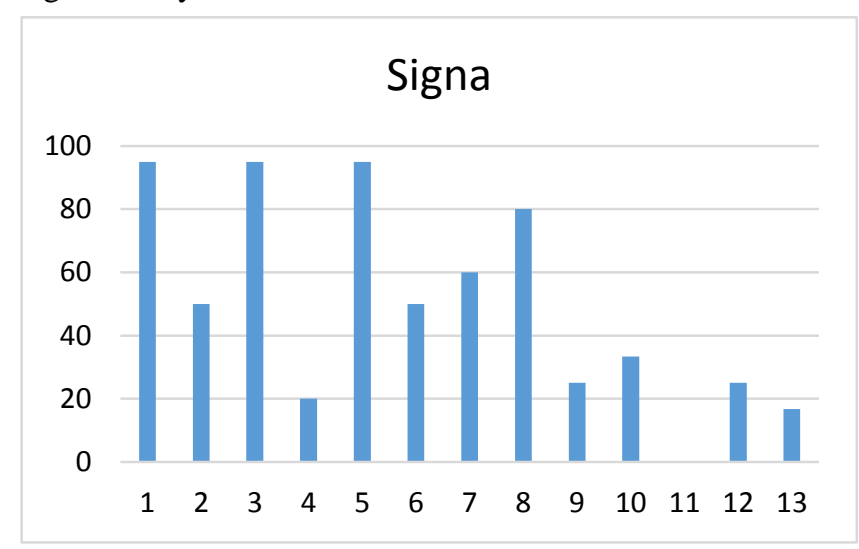

Fig. 4. Signa ${ }^{\circledR}$ transfer process capability profile.

The Signa ${ }^{\circledR}$ product line is mainly created by the same developer as InnoSPICE®; however, they are quite different solutions. Nevertheless, the transfer process capability profiles of Signa ${ }^{\circledR}$ and InnoSPICE ${ }^{\circledR}$ are quite similar. This fact brings up the idea that the transfer process capability profile reflects to a greater extent the characteristics of a technology developer as a transfer process performer rather than transferred knowledge or technology itself.

\section{CONCLUSION}

In order to validate the technology transfer model InnoSPICE, a generic questionnaire for the assessment of technology transfer processes was developed. Tailored questionnaires for the transfer cases of four piloting research results were developed and filled in. The technology transfer process capability was assessed for all 13 processes of the technology transfer process category. The transfer process capability assessment results are provided as process capability profiles for those piloting results. They reflect adequately particular features of the real knowledge and technology transfer, which was studied, and therefore validate the applicability of InnoSPICE model for technology transfer.

\section{ACKNOWLEDGEMENT}

The research has been funded by the Seventh Framework Programme project No. 600680 "ICT Transfer Concept for Adaptation, Dissemination and Local Exploitation of European Research Results in Central Asian Countries" (eINTERASIA).

\section{REFERENCES}

[1] Information Technology - Process Assessment - Part 2: Performing an Assessment. International Standards Organization, ISO/IEC 15504-2, 2003.

[2] Information Technology - Process Assessment - Part 5: An Exemplar Process Assessment Model. International Standards Organization, ISO/IEC 15504-5, 2006.

[3] CMMI-ACQ, 2010. CMMI for Acquisition, Version 1.3. Software Engineering Institute.

[4] CMMI-DEV, 2010. CMMI for Development, Version 1.3. Software Engineering Institute.

[5] CMMI-SVC, 2010. CMMI for Services, Version 1.3. Software Engineering Institute.

[6] Ibrahim, L., Bradford, B., Cole, D., et al., The Federal Aviation Administration Integrated Capability Maturity Model for Enterprise-wide Improvement. U.S. Federal Aviation Administration, FAA-iCMM, 2001.

[7] Ibrahim L., Jarzombek J., Ashford M., et al., Safety and Security Extensions for Integrated Capability Maturity Models. U.S. Federal Aviation Administration, 2004.

[8] Arelis, S., Besson, J., Mitašiūnas, J., et al., Enhanced innovation and technology transfer model. innoSPICE $®$ : Innovation, Knowledge- and Technology Transfer Capability Maturity Model. Version 1.0. pp. 1-132.

[9] Besson, J., Woronowicz, T., Mitasiunas, A., Boronowsky, M., "Innovation, Knowledge- and Technology Transfer Process Capability Model - innoSPICE ${ }^{\mathrm{TM}}$," The Proc. of the 12th Int. Conf., SPICE 2012, Palma, Spain, May 29-31, 2012; Software Process Improvement and Capability Determination Communications in Computer and Information Science, vol. 290, pp. 75-84, 2012. http://dx.doi.org/10.1007/978-3-64230439-2_7

[10] Boronowsky, M., Woronowicz, T., Mitasiunas, A., "BONITA - Improve Transfer from Universities for Regional Development," The Proc. of the 3rd ISPIM Innovation Symp. Quebec, Canada, Dec. 12-15, 2010, ISBN 978-952-265-004-7.

[11] Mitašiūnas, A., Novickis, L., "Enterprise SPICE based education capability maturity model. Workshops on business informatics research," Proc. Series: Lecture Notes in Business Information Processing, vol. 106 , pp. 102-116, 2012, ISSN 1865-1348, ISBN 9783642292309. http://dx.doi.org/10.1007/978-3-642-29231-6 9

[12] Gardner, P.L., Fong, A.Y., Graham, L.S., "From Innovation to Enterprise - the Role of Technology Commercialization in Sustaining Economic Growth," IEEE Technology Transfer Division, TRIUMF, Canada, 2004.

[13] Enterprise SPICE, "An Integrated Model for Enterprise-wide Assessment and Improvement Technical Report," Issue 1, Sept., 2010, [Online]. Available: http://www.enterprisespice.com/page/publication-1

[14] People Capability Maturity Model (P-CMM), Version 2.0, 2nd ed., Software Engineering Institute, Carnegie Mellon University, 2009. CMU/SEI-2009-TR-003, ESC-TR-2009-003, 2009.

[15] OECD, Oslo Manual. Guidelines for Collecting and Interpreting Innovation data. A Joint publication of OECD and Eurostat, 3rd ed., 2005.

[16] Bluemel, E., Strassburger, S., Novitsky, L., (Eds). "IT\&T Solutions in Logistics and Maritime Applications," Scientific Proc. of the project eLOGMAR-M, funded by the EC under $6^{\text {th }}$ FP. Jumi Ltd., Riga.

[17] Schenk, M., Blümel, E., Schumann, M., "VIVERA - virtual network of competence for virtual and augmented reality," in MicroCAD 2006; M szekció: Gépgyártástechnológia és gyártórendszerek. Miskolc: Univ., S. 123-126. Kongress: MicroCAD; March 16-17, 2006, ISBN 963-661$713-9$ 
[18] Mitašiūnas, A., Ragaišis, S., "Electronic documents interperability solutions in academic environment," 3rd int. workshop on intelligent educational systems and technology-enhanced learning : selected papers, INTEL-EDU 2012, Riga: JUMI Publishing House Ltd., pp. 21-34, Oct. $10-12,2012$.

Antanas Mitasiunas is the founder and chairman of the board of company MitSoft. He is also an Associate Professor of the Department of Computer Science at Vilnius University. He obtained a Doctoral Degree in Computer Science (Dr.sc.comp.) from Moscow State University in 1981. He was a national expert of the ICT Committee in FP7, member of advisory board of the international project Enterprice SPICE, expert of national European Structural Funds. Research areas: process capability maturity modeling, software design, software quality management, innovations and technology transfer.

E-mail: antanas.mitasiunass@mitsoft.lt

Jeremy Besson is a System Analyst and Java Developer at MitSoft company. He sometimes works as a Data Mining Consultant. He is also a Data Mining Lecturer at Vilnius University, the Statistic Department. His research interests focus on developing novel data mining techniques for applications in bioinformatics and digital advertising, and process-oriented innovation and export modelling. He was a key participant of the Baltic Sea Region INTERREG program project BONITA.

E-mail: jeremy.besson@gmail.com
Michael Boronowsky is a Managing Director of the Innovation Capability Unit at the Center for Computing and Communication Technologies, University of Bremen. In 1992, he finished his studies in electrical engineering at the University of Applied Science Aachen. Then he worked in a measurement device company as a Leading Development Engineer. He went back to the university and studied Computer Science in Nijmegen (Netherlands) and received a Master Degree in Computer Science in 1995. Since this time he has been working at the University of Bremen. In the beginning he was working in the area of Artificial Intelligence research. In 1999 he became responsible for coordinating the Wearable Computing research at the TZI. Dr. Boronowsky finished his Doctoral studies in 2001 and became a Managing Director of the Intelligent Systems Department. Since 2002 he has been a Managing Director of the TZI and has become a Manager of the Innovation Capability Unit this year. He coordinated the application of the IP-proposal "wearIT@work Empowering the Mobile Worker with Wearable Computing". He is an international expert in the field of knowledge and technology transfer and representative of the European Baltic Sea Region INTERREG 4B project BONITA.

E-mail: mb@tzi.de

Tanja Woronowicz is the Head of Development at the Innovation Capability Unit of TZI - University of Bremen. After 5 years in industry (sales management, HRD), she came back to the university in 2007, working as an IT Security Assessor (ISO 27001) and European Project Manager. Tanja holds a Master Degree in Geographical Information Systems from Paris-Lodron University in Salzburg, Austria. Tanja has been a Project Manager of the Baltic Sea Region project BONITA that has developed the Innovation, Knowledge and Technology Transfer capability model innoSPICE and is a co-author of innoSPICE standard based model. Tanja is also a Lecturer at Bremen University of Applied Sciences. She was a Manager and a Trainer in two projects to improve the knowledge and technology transfer capacity within the Lithuanian innovation system based on innoSPICE. She performed several assessments based on innoSPICE as a Lead Assessor at universities, research organizations, science parks in several European Countries.

E-mail: worono@tzi.de 